\section{Размышляя об истории Белого движения в Сибири}

О книге В.Г. Кокоулина «Белая Сибирь: борьба политических партий и групп (ноябрь 1918 - декабрь 1919 г.)». - Новосибирск: НВВКУ, 2017. - $528 \mathrm{c}$.

Более двадцати лет доктор исторических наук В.Г. Кокоулин работал над исследованием проблем социально-политической истории Сибири в годы революций и Гражданской войны. Так уже совпало, что эта книга новосибирского ученого, которая подводит итоги многолетнего всестороннего изучения темы, вышла в год столетнего юбилея российских революций 1917 г. Собрав и проанализировав большой фактический материал, автор смог написать работу, интересную не только профессионаламисторикам, но и философам, политологам, конфликтологам, социологам, экономистам

Автор открывает новые горизонты для дискуссий не только о прошлом нашего края и страны, но и об их ближайшем будущем. Одна из тем, затронутых в книге,--региональное управление и самоуправление. Еще сибирские областники во второй половине XIX в. вели активные дискуссии о необходимости особого подхода к управлению Сибирью, о ее частичной автономии и самоуправлении. В годы революции и Гражданской войны все возможные модели, предлагавшиеся тогда различными политическими партиями, от большевиков до кадетов, были реализованы на практике. Самой неудачной оказалась модель белого движения - авторитарное государство с минимальным самоуправлением регионов и полным отсутствием какой-либо автономии. Впрочем, как показал автор монографии, идеологи белого движения осознавали ущербность своей модели регионального управления и выдвигали тезис «непредрешения», откладывая окончательное урегулирование вопроса о государственном устройстве до Национального собрания, которое они планировали созвать после победы над большевиками на несколько иных основаниях, нежели Учредительное собрание. Аграрная политика белого режима в Сибири потерпела полный крах и завела его в исторический тупик - сибирское крестьянство после 15 месяцев революционных преобразований уже не соглашалось и никогда не согласилось бы вернуться к дореволюционным порядкам.

Избранный автором методологический подход сочетает классические принципы социально-исторического анализа с элементами клиодинамики, разрабатываемой такими известными современными исследователями, как Р. Коллинз, Н. С. Розов и др.

В.Г. Кокоулин показывает на конкретных примерах, что политические и военные руководители, лидеры политических партий и групп не всегда адекватно воспринимали быстро менявшуюся ситуацию, изменение соотношения и настроений различных социально-классовых сил, и поэтому не могли своевременно выработать соответствующую тактику действий, что приводило к падению их популярности и влияния в массах и предопределяло в конечном итоге их поражение.

Автор монографии предостерегает от восприятия военных и политических лидеров белого движения и их вождя адмирала А.В. Колчака как деятелей, которые только из-за своих «ошибочных действий» не смогли решить задачи общественного переустройства России. «Теория ошибок» была разработана в эмигрантской публицистике для оправдания поражения белого движения в годы Гражданской войны, но, к сожалению, многие современные историки по инерции используют этот устаревший методологический подход для анализа исторических процессов. А зачастую подменяют и само изучение исторических реалий исследованием «миражей»-искусственно созданных идеологических конструкций или агитационно-пропагандистских лозунгов тех или иных политических партий и групп.

Хочется отметить, что в книге военно-политические и революционные события рассматриваются с самых разных сторонглазами военных и политиков, торговцев и промышленников, крестьян и рабочих, городских обывателей и лидеров политических партий. Автор приводит яркие эпизоды политической борьбы, изложенные с позиции той или иной группы, прибегая к такому приему, как воспроизведение «прямой речи» исторического персонажа (текст выступления на партийном совещании, заседании городской думы или в газете). Это позволяет передать не только «колорит эпохи», но и видение ситуации глазами современников. В итоге события революций и Гражданской войны 
освещаются с разных сторон - из нашего исторического «далёка» и на событийном горизонте человека той эпохи, что порождает своего рода «стереоскопический эффект».

В заключение отметим, что новая книга В.Г. Кокоулина интересна не только живым изложением и нестандартным анализом событий столетней давности. Многие из проблем, которые автор затрагивает в своем исследовании, актуальны и сегодня. Ведь на новом витке отечественной истории мы вновь оказались в ситуации послереволюционной России с ее многопартийностью, конкуренцией политических партий, их программ и идеологий. Снова возродились дискуссии о региональном управлении, взаимоотношении центра и регионов, идут жаркие споры о будущем России. Книга о белом движении вновь заставляет задуматься о наших современных геополитических интересах, союзниках и конкурентах, о модели экономического и социального развития такого огромного российского региона, как Сибирь.

В.Ю. БАЛАБУШЕВИЧ, кандидат философСких наук, Новосибирское высшее военное командное училище 